\title{
First description of the male of Philometroides acreanensis and phylogenetic assessment of Philometridae (Nematoda: Dracunculoidea) suggest instability of some taxa
}

\author{
Luciano P. Negreiros $^{\mathrm{a}}$, Marcos Tavares-Dias ${ }^{\mathrm{b}}$, Carina Elisei ${ }^{\mathrm{c}}$, Luiz E.R. Tavares ${ }^{\mathrm{d}}$, \\ Felipe B. Pereira ${ }^{\mathrm{d}, *}$ \\ a Universidade Federal do Amapá, Pós-Graduação Rede de Biodiversidade e Biotecnologia da Amazônia (PPG-BIONORTE), Rodovia Juscelino Kubitschek, Km 02, \\ Universidade, 68902-280 Macapá, AP, Brazil \\ ${ }^{\mathrm{b}}$ Embrapa Amapá, Setor de Sanidade de Organismos Aquáticos. Rodovia Juscelino Kubitschek, km 5, 2600, CEP 68903-419 Macapá, AP, Brazil \\ ${ }^{\mathrm{c}}$ Programa de Pós-Graduação em Biotecnologia, Universidade Católica Dom Bosco, Av. Tamandaré 6000, Jardim Seminário, CEP 79117-900 Campo Grande, MS, Brazil \\ ${ }^{\mathrm{d}}$ Programa de Pós-Graduação em Biologia Animal, Instituto de Biociências (INBIO), Universidade Federal de Mato Grosso do Sul (UFMS), Av. Costa e Silva s/ ${ }^{\circ}$, CEP \\ 79070-900 Campo Grande, MS, Brazil
}

\section{A R T I C L E I N F O}

\section{Keywords:}

Parasite

Freshwater catfish

Pimelodus blochii

Brazil

Amazonia

Genetic characterization

\begin{abstract}
A B S T R A C T
The male of Philometroides acreanensis, parasitic in the anterior intestine external wall of the freshwater catfish Pimelodus blochii, from the Brazilian Amazon, is described for the first time. Additional data on the morphology of females is given. The new morphological data strengthened the validity of the species as well as its first genetic characterization, using three nuclear genetic markers (18S and 28S of the rDNA and ITS1-58S-ITS2), confirmed the high genetic resemblance of male and female specimens. Philometroides acreanensis shows morphological features of the generic diagnosis of Neophilometroides, Alinema, Philometra and Philometroides. Phylogenetic analyses using sequences of the18S rDNA from representatives of Dracunculoidea confirmed the validity of $P$. acreanensis and its close relatedness with Alinema rather than with other genera. The validity of Philonemidae was confirmed, as was the monophyly of Philometridae and Clavinema. However, Dentiphilometra, Philometra and Philometroides appear not to be monophyletic. Host taxa, habitat and geographic occurrence seem to have some relationship with the evolutionary traits of certain phylogenetic assemblages of philometrids, which were highly supported in the phylogentic reconstructions. Even though interesting aspects of the phylogeny and taxonomy of Philometridae came to light, further integrative approaches should be used that include additional genetic markers, due to the loose boundaries between some genera as observed here.
\end{abstract}

\section{Introduction}

Philometridae represents a highly diverse family of nematode parasites in fishes from most of the aquatic ecosystems [1]. Despite their high diversification and improvement of the related genetic database, deep phylogenetic analyses within Philometridae are scarce (see [1-3]). Such approaches should be better explored, since the validity and the diagnosis of some genera have been questioned following phylogenetic analyses (e.g. [2-5]).

Recently, Philometroides acreanensis was described based on female specimens parasitizing the catfish Pimelodus blochii from River Acre, State of Acre, Brazil [6]. The description of new species of philometrids based solely on gravid females is common, because males are very small, difficult to find and may occupy different sites of infection than those of females [1]. However, the morphology of males is crucial to sustain the specific taxa, as well as the genetic characterization of species, in order to improve the current knowledge and clarify the taxonomic confusions.

During a parasitological sampling in the Brazilian Amazon, male and female specimens of $P$. acreanensis were recovered from $P$. blochii in the River Acre. Therefore, due to the previously highlighted issues, the present goals were to: (i) provide the first description of the male of the species and additional data on the females, using light and scanning electron microscopy (SEM), (ii) provide the first genetic characterization of the species based on regions of the nuclear genomic DNA, (iii) assess and discuss the taxonomic and the phylogenetic aspects of taxa belonging to Philometridae, based on phylogenetic reconstructions using sequences of the $18 \mathrm{~S}$ (SSU) rRNA gene and, (iv) verify the validity

\footnotetext{
* Corresponding author.

E-mail address: felipebisaggiop@hotmail.com (F.B. Pereira).
} 
of Philonemidae sensu [3] and the monophyly of Philometridae, after inclusion of new sequences in a broad analysis.

\section{Materials and methods}

\subsection{Collection, processing and morphological examination of parasites}

In January and June of 2015-2017, 80 specimens of $P$. blochii (total body length $11-18 \mathrm{~cm}$; weight $33-118 \mathrm{~g}$ ) were collected by local fisherman in River Acre, municipality of Rio Branco, State of Acre, Brazil. Host nomenclature and classification follows [7]. All procedures involving animals were authorized by the Instituto Chico Mendes para Conservação da Biodiversidade (acronym ICMBio, $\mathrm{N}^{\circ}$ 60899-1) and were strictly according to the protocols and rules of the Committee on Ethics of Animal Use of the Embrapa Amapá (Protocol: No 002- CEUACPAFAP). Freshly dead fish were immediately brought to the laboratory in insulated boxes filled with ice and dissected. All the organs were separated in Petri dishes containing saline $(0.9 \% \mathrm{NaCl})$ and observed under a stereomicroscope. Nematodes were found alive and washed in saline; two entire females and an anterior fragment of a third were fixed in hot $4 \%$ formaldehyde solution, the only male was killed with hot water; all specimens were preserved in $70 \%$ ethanol. For genetic studies, half of another anterior fragment from a broken female was excised and stored directly in 96-99\% molecular grade ethanol; the rest was fixed in $4 \%$ formalin for morphological identification and SEM observations. The total body length of the male was measured using a Leica M205C stereomicroscope with the imaging system LAS V3.8 (Leica, Switzerland), keeping sterile environment in order to avoid contamination; then, a small part of its mid body was taken for genetic study and the rest used for morphological examinations.

Nematodes were cleared in glycerin for observation under the light microscope. Drawings and measurements were made using a drawing tube attached to a microscope Olympus BX51. Measurements are given in micrometers, unless otherwise stated. Samples used for scanning electron microscopy (SEM) (i.e., two anterior parts of female specimens, and, posterior and anterior parts of the male) were dehydrated through a graded ethanol series, dried by evaporation with hexamethyl disilazane, coated with gold and examined in a JEOL JSM 6460-LV, at an accelerating voltage of $15 \mathrm{kV}$. Systematic classification of higher taxa of parasites follows [8] and is updated according to [3]. Vouchers were deposited in the Coleção Zoológica da Universidade Federal de Mato Grosso do Sul (acronym ZUFMS).

\subsection{DNA isolation, PCR and sequencing}

Genomic DNA was isolated using DNeasy Blood \& Tissue Kit (QIAGEN, Hilden, Germany), following the manufacturer's instructions. Three regions of the genomic nuclear DNA were amplified, one corresponding to the $5^{\prime}$ end of the $18 \mathrm{~S}$ rDNA, one comprising the regions D2 and D3 of the 28S rDNA and that comprising the ITS1-5.8S-ITS2. All PCR reactions and cycling conditions are detailed in the Supplementary material S1; primers were those of [9-11]. PCR products were purified through an enzymatic treatment with ExoProStar ${ }^{\mathrm{TM}}$ (GE Helathcare) and sent for sequencing at ACTGene (Ludwig Biotec, Rio Grande do Sul, Brazil) with the same primers used in PCR reactions.

\subsection{Genetic comparisons and phylogenetic analyses}

Contiguous sequences were assembled in Geneious (Geneious ver. 9.1.5 created by Biomatters, available from http://www.geneious.com/ ) and deposited in the GenBank (see taxonomic summary for accession numbers). Preliminary BLAST search on GenBank database (https:// www.ncbi.nlm.nih.gov/genbank/) was performed to confirm the genetic proximity between the present sequences and those from representatives of Dracunculoidea/Philometridae. Sequences of the 18S, $28 \mathrm{~S}$ and ITS1-5.8S-ITS2 from the male and from the female of $P$. acreanensis were aligned separately, using the algorithm E-INS-i of the program MAFFT [12] for comparative purposes.

Additionally, sequences of the 18S and 28S rDNA from Philometra nattereri parasitic in Serrasalmus gibbus from River Araguari, State of Amapá, Brazil, obtained during 2014 in the Institute of Parasitology, Biology Centre of the Czech Academy of Sciences (acronym IPCAS) are generated for the first time (GenBank accession numbers MH930986, MH930985).

Sequences from all representatives of Dracunculoidea (including that of $P$. nattereri) corresponding to the $5^{\prime}$ end of the $18 \mathrm{~S}$ (about $850 \mathrm{bp}$ ) were retrieved from GenBank for phylogenetic reconstructions (see Table 1); sequences from same isolate or clones with $100 \%$ of genetic similarity were not included. These representatives were chosen in order to verify the validity of Philonemidae (see [3]), as well as to infer the phylogenetic position of $P$. acreanensis and the relationships among taxa of Philometridae. Camallanus cotti was taken as outgroup based on previous phylogenies ([3]). Sequences were aligned using MCofee [13], then evaluated by the transitive consistency score (TCS), to verify the reliability of aligned positions and, based on score values, ambiguous aligned positions were trimmed [14]. Dataset was subjected to maximum likelihood (ML) and Bayesian inference (BI) analyses, generating trees under the GTR + I + G model of evolution using PHYML [15] and MrBayes [16], respectively. The model of evolution and its fixed parameters were chosen and generated under the Akaike information criterion, using jModelTest 2 [15,17]. Bayesian posterior probability values were determined after running the Markov chain Monte Carlo (2 runs 4 chains) for $4 \times 10^{6}$ generations, with sampling frequency every $4 \times 10^{3}$ generations and discarding the initial $1 / 4$ of sampled trees $\left(1 \times 10^{6}\right)$ as bur-in. For ML analysis, bootstrap resampling was performed with 1000 non-parametric replications.

Due to the scarcity of data, phylogenetic reconstructions using $28 \mathrm{~S}$ sequences were not performed, and those using the ITS1-5.8S-ITS2 with all the related details are given in the Supplementary material S2 (A, B), but not highlighted here.

\section{Results}

\subsection{Morphological description}

Dracunculoidea

Philometridae

Philometroides

Philometroides acreanensis (Figs. 1, 2)

Type host and from the study: Pimelodus blochii (Silurifores: Pimelodidae).

Type locality and from the present study: River Acre, Municipality of Rio Branco, State of Acre, Brazil (GPS data not available).

Site of infection: females in the external serous of stomach wall, males in the external serous of anterior intestine.

Prevalence: 3 fish infected of 80 examined (3.8\%), all collected during the rainy season.

Deposition of specimens: 2 females in ethanol 70\%; 1 male and 2 anterior fragments of females mounted and coated with gold on stub (ZUFMS-NEM0053, 54).

GenBank accession numbers: female MH923190 18S, MH923192 28S, MH923188 ITS1-5.8S-ITS2; male MH923191 18S, MH923193 28S, MH923189 ITS1-5.8S-ITS2.

3.1.1. Additional data on the morphology of females and first-stage larvae (based on 2 gravid specimens and 1 anterior fragment)

Cephalic end with oval oral opening located on slight furrow, lacking marginal denticles and bearing three rounded labia (Figs. 1C, 2A-C). Cepahlic papillae very small, outer circle composed of 4 submedian pairs, inner circle with 4 submedian single papillae plus pair of minute lateral papilla-like amphids (Figs. 2A-C). Small oral cavity present, weakly cuticularised, 5-7 long and 5 wide (Fig. 1E). Body 
Table 1

Species of dacunculloid nematodes (Nematoda: Dracunculoidea), plus outgroup, whose sequences of the 18S rDNA were retrieved from GenBank for phylogenetic reconstructions, associated with host species, habitat, geographic origin and accession numbers.

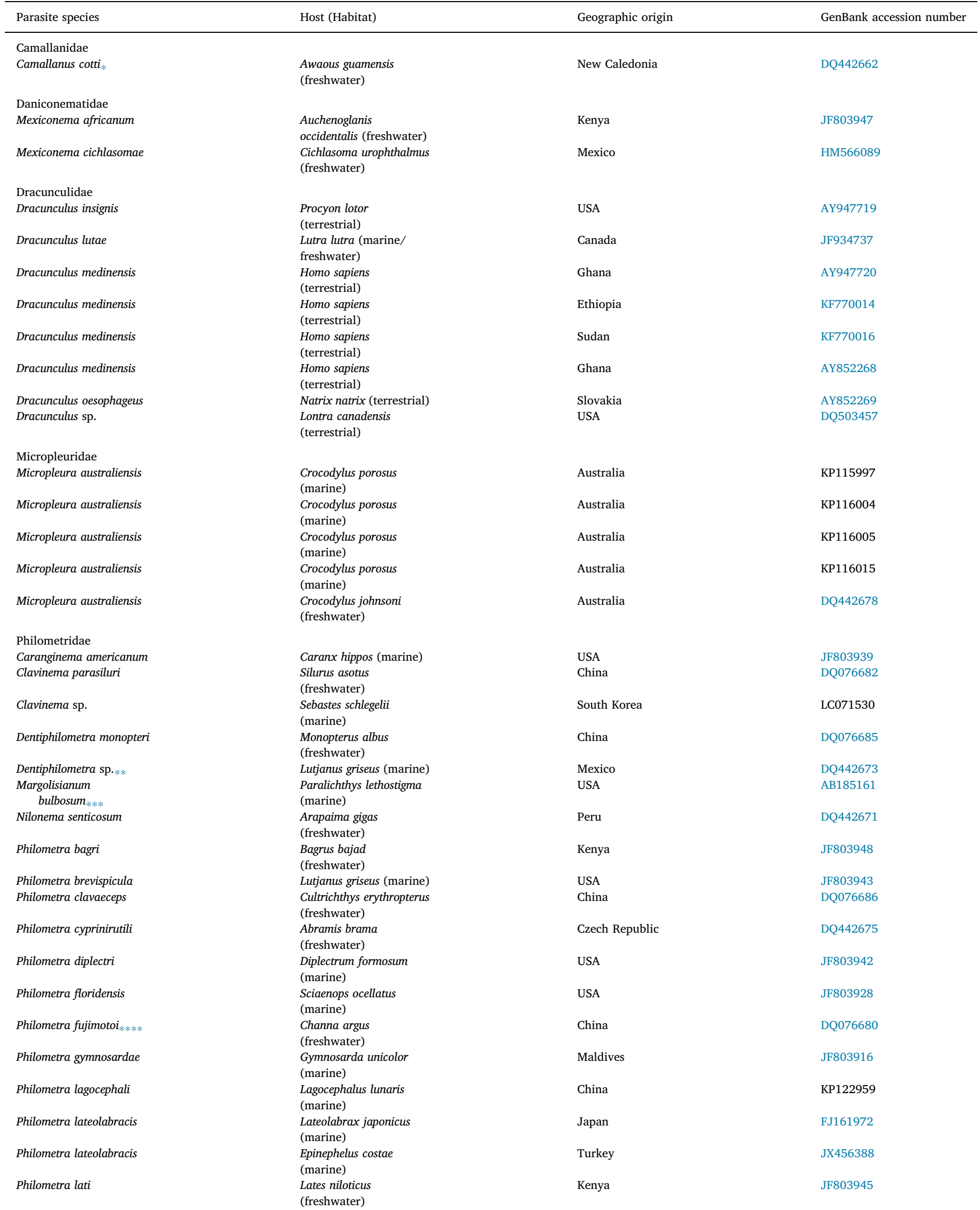


Table 1 (continued)

\begin{tabular}{|c|c|c|c|}
\hline Parasite species & Host (Habitat) & Geographic origin & GenBank accession number \\
\hline Philometra madai & Pagrus major (marine) & Japan & FJ161974 \\
\hline Philometra morii & $\begin{array}{l}\text { Epinephelus morio } \\
\text { (marine) }\end{array}$ & USA & JF803933 \\
\hline Philometra nemipteri & $\begin{array}{l}\text { Nemipterus virgatus } \\
\text { (marine) }\end{array}$ & Japan & FJ161975 \\
\hline Philometra obturans & Esox lucius (freshwater) & Czech Republic & AY852267 \\
\hline Philometra ocularis & $\begin{array}{l}\text { Epinephelus areolatus } \\
\text { (marine) }\end{array}$ & New Caledonia & JF803929 \\
\hline Philometra ovata & Gobio gobio & Czech Republic & DQ442677 \\
\hline Philometra philippinensis & $\begin{array}{l}\text { Sphyraena forsteri } \\
\text { (marine) }\end{array}$ & Philippines & KC342903 \\
\hline Philometra philippinensis & $\begin{array}{l}\text { Sphyraena forsteri } \\
\text { (marine) }\end{array}$ & Philippines & КС342903 \\
\hline Philometra philippinensis & $\begin{array}{l}\text { Sphyraena forsteri } \\
\text { (marine) }\end{array}$ & Philippines & KC342903 \\
\hline Philometra spiriformis & $\begin{array}{l}\text { Lates niloticus } \\
\text { (freshwater) }\end{array}$ & Kenya & JF803944 \\
\hline Philometra thaiensis & $\begin{array}{l}\text { Tetraodon biocellatus } \\
\text { (freshwater) }\end{array}$ & Thailand & KC894068 \\
\hline Philometra sp. & $\begin{array}{l}\text { Mycteroperca microlepis } \\
\text { (marine) }\end{array}$ & USA & JF803940 \\
\hline Philometra sp. & $\begin{array}{l}\text { Siniperca chuatsi } \\
\text { (freshwater) }\end{array}$ & China & EF127905 \\
\hline Philometra sp. & No information & No information & DQ442674 \\
\hline $\begin{array}{l}\text { Philometroides } \\
\text { branchiostegi }\end{array}$ & $\begin{array}{l}\text { Branchiostegus japonicus } \\
\text { (marine) }\end{array}$ & Japan & LC367611 \\
\hline Philometroides carassii & $\begin{array}{l}\text { Carassius auratus } \\
\text { (freshwater) }\end{array}$ & China & DQ076683 \\
\hline Philometroides cyprini & $\begin{array}{l}\text { Cyprinus carpio } \\
\text { (freshwater) }\end{array}$ & China & DQ076688 \\
\hline Philometroides fulvidraconi & $\begin{array}{l}\text { Pelteobagrus fulvidraco } \\
\text { (freshwater) }\end{array}$ & China & DQ076684 \\
\hline $\begin{array}{l}\text { Philometroides } \\
\text { ganzhounensis }\end{array}$ & $\begin{array}{l}\text { Hemibarbus maculates } \\
\text { (freshwater) }\end{array}$ & China & DQ076681 \\
\hline $\begin{array}{l}\text { Philometroides } \\
\text { grandipapillatus }\end{array}$ & Caranx hippos (marine) & USA & JF803941 \\
\hline $\begin{array}{l}\text { Philometroides } \\
\text { pseudorasbori }\end{array}$ & $\begin{array}{l}\text { Pseudorabora parva } \\
\text { (freshwater) }\end{array}$ & China & DQ076687 \\
\hline Philometroides sanguineus & $\begin{array}{l}\text { Carassius carassius } \\
\text { (freshwater) }\end{array}$ & England & DQ442676 \\
\hline Philometroides seriolae & $\begin{array}{l}\text { Seriola quinqueradiata } \\
\text { (marine) }\end{array}$ & Japan & FJ155811 \\
\hline Rumai rumai & $\begin{array}{l}\text { Arapaima gigas } \\
\text { (freshwater) }\end{array}$ & Brazil & JF803923 \\
\hline \multicolumn{4}{|l|}{ Philonemidae } \\
\hline Philonema oncorhynchi & $\begin{array}{l}\text { Oncorhynchus kisutch } \\
\text { (freshwater) }\end{array}$ & Canada & DQ442670 \\
\hline Philonema sp. & No information & USA & U81574 \\
\hline \multicolumn{4}{|l|}{ Skrjabillanidae } \\
\hline Esocinema bohemicum & Esox lucius (freshwater) & Russia & JF803917 \\
\hline Molnaria intestinalis & $\begin{array}{l}\text { Scardinius } \\
\text { erythrophthalmus } \\
\text { (freshwater) }\end{array}$ & Czech Republic & DQ442668 \\
\hline Skrjabillanus scardinii & $\begin{array}{l}\text { Scardinius } \\
\text { erythrophthalmus } \\
\text { (freshwater) }\end{array}$ & Czech Republic & DQ442669 \\
\hline
\end{tabular}

* Used as outgroup.

** Probably D. lutjani.

*** Genus and species inquirendae.

**** Valid name is Clavinema fujimotoi. 

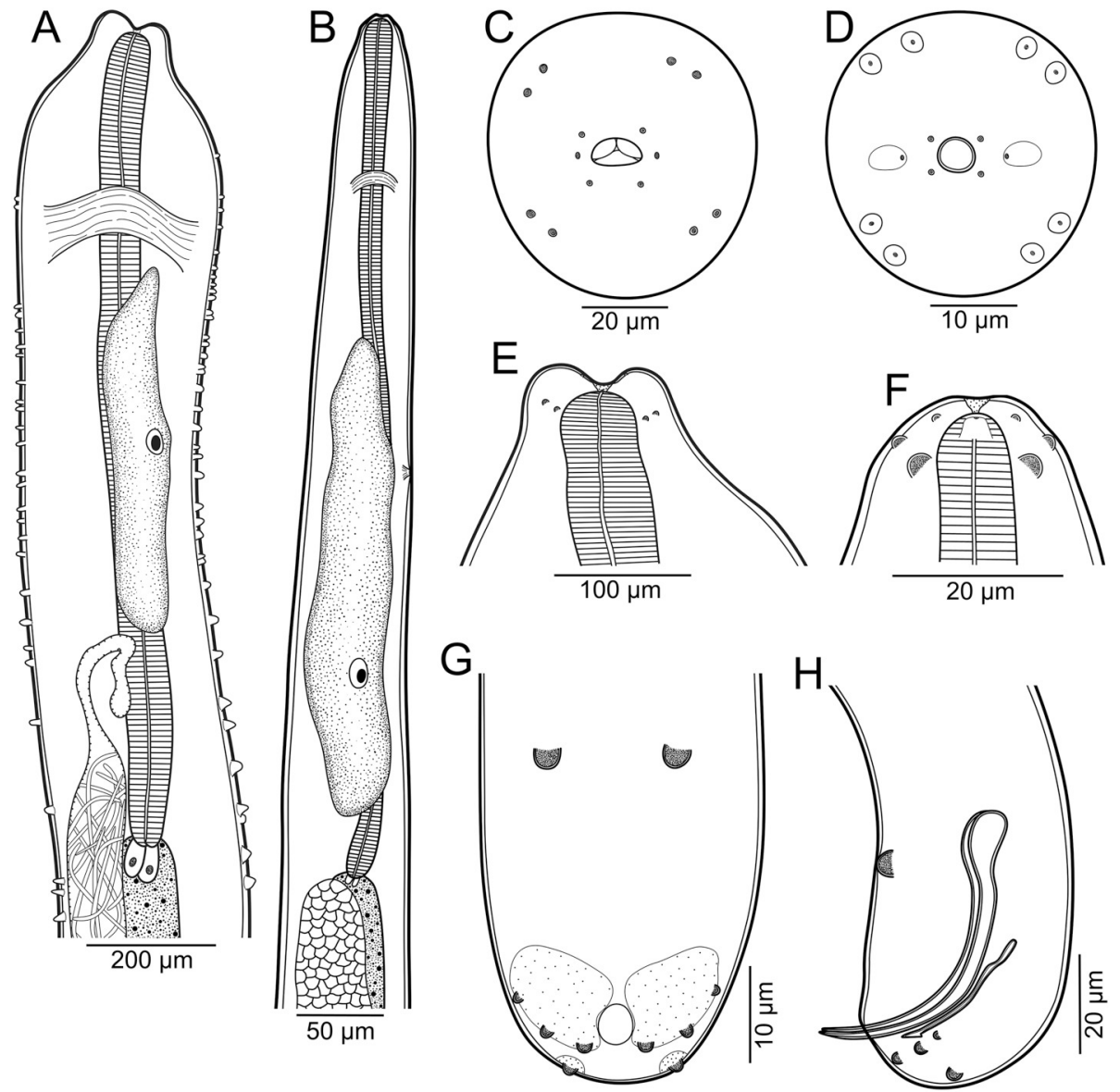

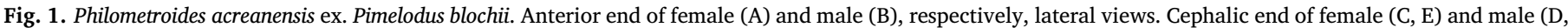
F), apical and lateral views, respectively. Posterior end of male, ventral (G) and lateral (H) view.

length $145-178 \mathrm{~mm}$, maximum width 391-424. Nerve ring 269-270 from anterior end (Fig. 1A). Oesophagus muscular with homogeneous width, $1.21-1.11 \mathrm{~mm}$ long and 54-64 wide, representing $0.7-0.8 \%$ of total body length (Fig. 1A). Oesophageal gland 420-500 long and 51 wide, extending from slight distance posterior to nerve ring until beginning of last $1 / 3$ of oesophagus, with single nucleus 572 from anterior end (Fig. 1A). Ligament attaching posterior end of intestine to body wall near caudal end, 135-234 long. Ovaries narrow and short, bending near anterior and posterior ends of body. Uterus occupying major part of body filled with first-stage larvae 305-320 long, 20 wide. First-stage larva with elliptical oral opening and cephalic end bearing two very small papillae, observed only using SEM (Fig. 2E).

\subsubsection{Male (based on one adult specimen)}

Small translucent nematode, $3.5 \mathrm{~mm}$ long and 80 wide. Cuticle without bosses. Cephalic end rounded with circular oral opening, without marginal denticles (Fig. 1D). Outer circle of cephalic papillae composed of 4 submedian pairs, inner circle with 4 smaller submedian single papillae and pair of small lateral amphids opening on proximal top of ellipsoid cuticular cephalic elevations (Figs. 1D, F, 2D). Minute funnel-shaped oral cavity, weakly cuticularised, 3 long and 3 of maximum width (Fig. 1F). Nerve ring and excretory pore 87 and 241, respectively, from anterior end (Fig. 1B). Oesophagus muscular, narrow, lacking inflations, opening into intestine trough small ventricular valve, 452 long and 20 wide; representing $12.9 \%$ of total body length (Fig. 1B). Oesophageal gland well-developed 275 long and 50 of maximum width, extending from beginning of second $1 / 3$ of oesophagus to near its end, with single nucleus 342 from anterior end (Fig. 1B). Posterior end of body rounded, with smooth ventral bend (Fig. 1H). Spicules equal, with enlarged and thin proximal and distal ends, respectively, 63 long, representing $1.8 \%$ of total body length (Fig. 1H). Gubernaculum harpoon-shaped with smooth constriction near proximal end, 39 long (Fig. 1H). Cloacal opening circular, at short distance from caudal end and flanked by two large cuticular swellings (Figs. 1G, 2F, $\mathrm{G})$. One pair of large precloacal papillae far anterior from cloacal opening (Figs. 1G, H, 2F). Three pairs of medium-sized caudal papillae on cuticular swellings: first pair lateral and slightly precloacal, second pair sublateral and adcloacal, third pair ventral and slightly postcolacal (Figs. 1G, H, 2G). One pair of medium-size papillae located on subterminal lateral cuticular swellings (Figs. 1G, H, 2G).

\subsubsection{Remarks}

Philometroides acreanensis was recently described based on two gravid females [6], which is commonly observed in Philometridae $[1,18]$. Even though the present specimens showed slight differences from those described by [6], mainly regarding the total body length (145-178 vs. $240-280 \mathrm{~mm}$ ), there is no evidence that they belong to a different species, since they were collected in the same fish and locality as the type host ( $P$. blochii) and locality (River Acre) of P. acreanensis $[6]$.

The present observations revealed some features described for the first time in the females of $P$. acreanensis, i.e., the accurate morphology of cephalic structures (cephalic papillae and amphids), presence of small oral cavity with smooth cuticularisation, position of nerve ring, length of intestinal ligament and presence of cephalic papillae on the first-stage larvae. Some differences were also noted between the newly collected females and those from the original description in respect to the extension of ovaries (short vs. long), as well as in the length of oesophageal gland (420-500 vs. 330) [6]. However, these differences may be accounted by the ontogeny of the parasite, since samples 

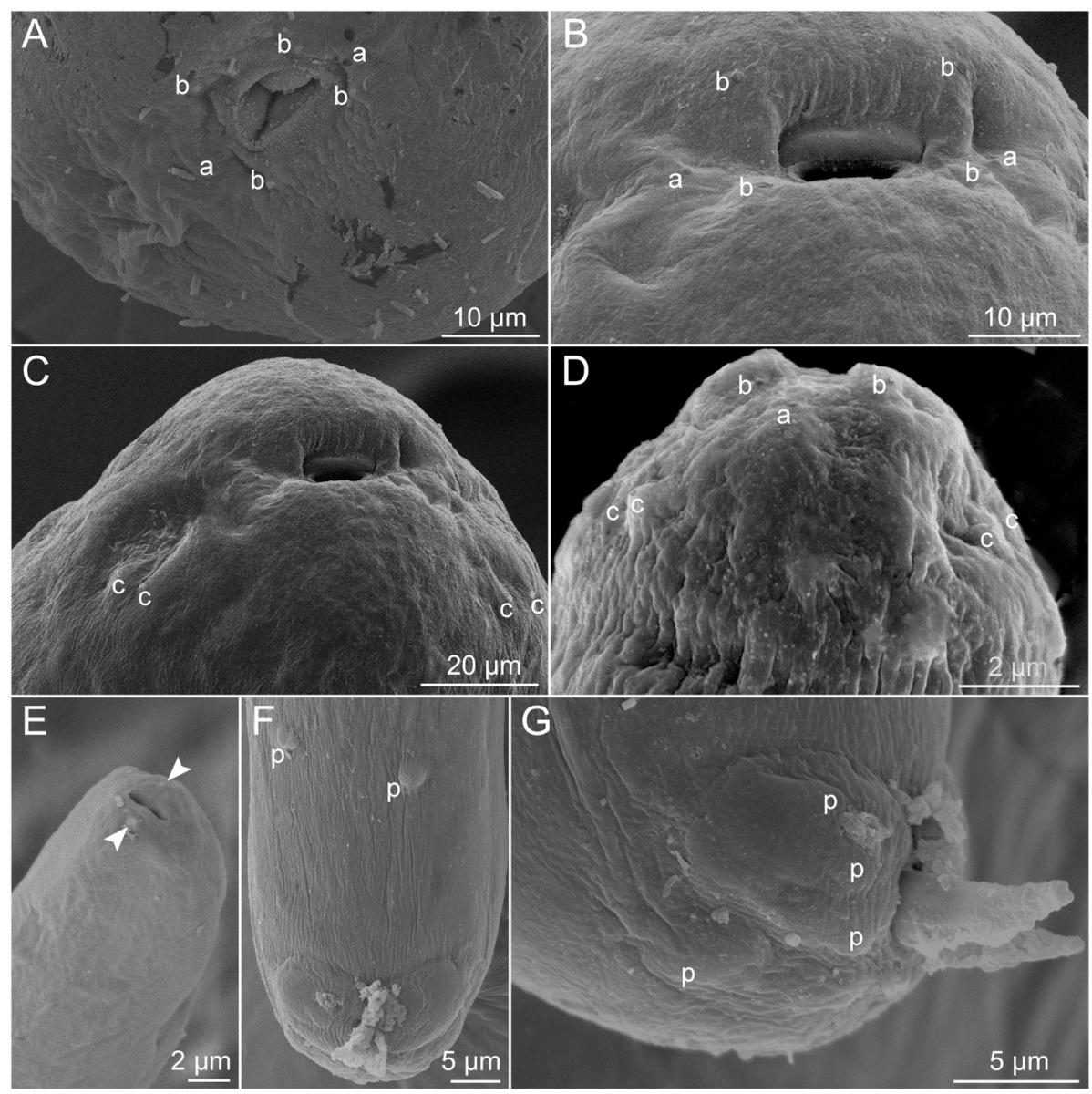

showed substantial differences in the total body length, and/or some influence of fixation procedures (these parasites are very sensitive to osmosis). Furthermore, it should be mentioned that based on the scale bar related to Fig. 1A of [6], the oesophageal gland length is at least twice as large as is indicated in the text. Because of the detailed description of females of $P$. acreanensis provided by [6], we refrain from detail other morphological aspects here.

The male of $P$. acreanensis is described here for the first time. It is very interesting that the general morphology of the specimen resembles most males from different genera, i.e., Alinema and Neophilometroides (see [8]), mainly regarding the caudal structures (cloacal opening position, general arrangement of caudal papillae, general structure of spicules and gubernaculum). Therefore, the male of $P$. acreanensis clearly differs from all its congeners as well as from the species allocated in the monospecific genera Alinema and Nemophilometroides namely, A. amazonicum and $N$. caudatus by a combination of several features, e.g., the morphology of gubernaculum and spicules, structure of the oesophageal gland, number and arrangement of caudal papillae (see [8]). In this sense, and along with the morphological aspects showed by females as remarked in [6], the validity of $P$. acreanensis was confirmed, even though its generic allocation and, most likely, the generic status of Neophilometroides should be re-evaluated (see the discussion for more details).

\subsection{Genetic characterization}

Partial sequences of the $18 \mathrm{~S}$ ( 825 and $845 \mathrm{bp}$ ) and $28 \mathrm{~S}$ ( 865 and $866 \mathrm{bp}$ ) of the rDNA, and of the ITS1-5.8S-ITS2 (1000 and $1014 \mathrm{bp}$ ) were obtained for both male and female of $P$. acreanensis, in which $18 \mathrm{~S}$ and $28 \mathrm{~S}$ sequences were $100 \%$ identical between the specimens and those of ITS1-5.8S-ITS2 were $99.75 \%$ identical, showing only two polymorphic sites. Blast search confirmed the genetic proximity of the present specimens with those belonging to Philometridae.

Additionally, partial sequences of the $18 \mathrm{~S}$ ( $943 \mathrm{bp}$ ) and $28 \mathrm{~S}$ ( $995 \mathrm{bp}$ ) rDNA were obtained for a female of $P$. nattereri, showing $93.68 \%$ and $87.26 \%$, respectively, of genetic similarity with those of the $18 \mathrm{~S}$ and $28 \mathrm{~S}$ of $P$. acreanensis.

\subsection{Phylogenetic analyses}

Phylogenetic reconstructions using ML and BI exhibited the same pattern and nodal support values. In the assemblage formed by representatives of the superfamily Dracunculoidea, Skrjabillanidae appeared as polyphyletic whereas Philometridae the genera Dracunculus, Mexiconema, Micropleura and Philonema appeared as monophyletic with high nodal supports (Fig. 3).

Within Philometridae, $P$. acreanensis formed a well-supported clade with A. amazonicum as a sister group of Nilonema senticosum and Rumai rumai (Fig. 3). Philometra nattereri grouped with Caranginema americacum and Philometra floridensis in a well-supported group far from that of $P$. acreanensis (Fig. 3). The genera Philometra and Philometroides were polyphyletic and, suggestively, Clavinema and Dentiphilometra were not monophyletic. Interestingly, Philometra philippinensis appeared as paraphyletic with high nodal supports, and some assemblages of philometrids were formed according to affinities on habitat (freshwater or marine), host taxon (Order level) and/or geographic occurrence (continent), with moderate to high nodal support (Fig. 3).

\section{Discussion}

Present results of the genetic characterization confirmed the high genetic similarity of both male and female specimens, accordingly 


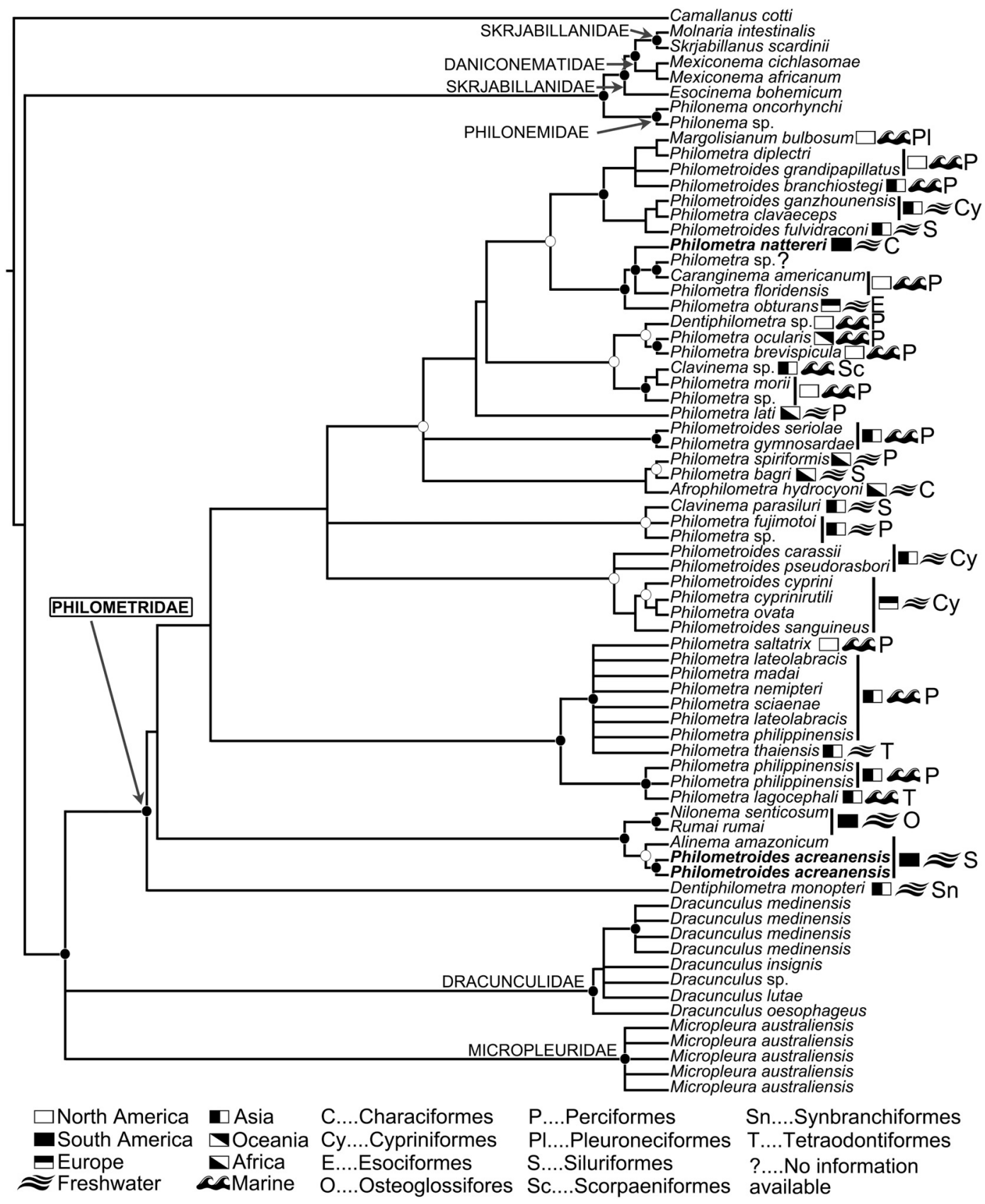

Fig. 3. Phylogenetic tree generated from Bayesian inference from sequences of dracunculoid nematodes (Nematoda: Dracunculoidea), with the respective families indicated. Within Philometridae there are indication on host Order, habitat and geographic origin for each sequence. Sequences in bold are from the present study. Camallanus cotti is the outgroup. Full circles represent nodal supports $>0.96$ Bayesian posterior probability (BPP) $\left(4 \times 10^{6}\right.$ generations, sampling frequency $=4 \times 10^{3}$, bur-in $=1 \times 10^{6}$ ) and $>95 \%$ bootstrap resampling (1000 replications). Empty circles represent nodal supports $>0,90$ and $<0.96$ for BPP, and $>86 \%$ and $<95 \%$ for bootstrap.

assigned to $P$. acreanensis. On one hand, the morphology of the male suggests its close relatedness with $N$. caudatus, consequently distancing it from species of Philometroides. On the other hand, the female of $P$. acreanensis lacks most of the morphological features present in the diagnosis of Neophilometroides. Furthermore, minor but important features of males of Neophilometroides are lacking in that of $P$. acreanensis.

In the phylogenetic reconstruction, $P$. acreanensis appeared far from the species of Philometroides, but close to A. amazonicum. The morphology of males from both species is also closely related, regarding the general structure of caudal region, especially that of the gubernaculum and the arrangement of caudal papillae (see [8] for details on the morphology o A. amazonicum). Unfortunately, there are no genetic data available for $N$. caudatus to test its phylogenetic relationship with $A$. amazonicum and $P$. acreanensis.

As a consequence, $P$. acreanensis can be considered morphologically similar to both Neophilometroides and Philometroides, regarding a generic point of view. At the same time the species exhibits diagnostic features of Neophilometroides absent in Philometroides, e.g., presence of minute sclerotised oral cavity (that may be interpreted as a buccal capsule), cloaca at some distance from the caudal extremity and one pair of large precloacal papillae; the species has features of Philometroides that are absent in Neophilometroides, e.g., absence of peribuccal teeth, anus atrophied in females and presence of postcloacal papillae ([8]).

The previous discussion suggests that the validity of Neophilometroides is questionable, as same as that of Philometroides after 
phylogenetic approaches ([2,3] present study). In fact, generic allocations of species within Philometridae based on morphological traits have been confused, mainly related to Philometra, Philometroides and Neophilometroides (see [8] for a list of many cases of synonymy). Furthermore, the genetic studies have been indicating the artificiality of Philometroides $([2,3,19])$. Once cannot rule out that both Neophilometroides and Philometroides should represent a synonym of Philometra. However, we believe it is prudent to consider all the referred taxa as valid for now and $P$. acreanensis retained in Philometroides, until knowledge of genetics, morphology and biodiversity is improved.

It should be mentioned that Margolisianum bulbosum is considered genus and species inquirendae, representing a association of two different species, i.e., Philometra overstreeti and Philometroides paralichthydis [20]. Thus, the sequence referred to this taxon cannot be discussed from a phylogenetic perspective, since the isolation source is indeed undefined.

Philometra philippinensis appeared as paraphyletic in two distinct well-supported lineages. After aligning the three sequences of this species, we noted 12 polymorphic sites in the $18 \mathrm{~S}$, which is relatively substantial considering its high degree of conservation. It cannot be explained here, but contiguous edition errors cannot be discarded.

The phylogenetic reconstructions showed that within Dracunculoidea, Philonema was clearly separated from representatives of Philometridae, supporting the erection of Philonemidae by [3], consequently the monophyly of Philometridae was reinforced, even after inclusion of sequences additional to those in $[2,3]$. Moreover, the polyphyly of Philometra and Philometroides was confirmed as previously suggested $([1-3,19])$. Similar results were observed in the phylogenetic trees generated from sequences of the ITS1-5.8S-ITS2 and showed in the supplementary material S2A, B.

Clavinema appeared in two different clades formed by species of Philometra, suggesting its lack of monophyly. However, the sequence LC07153, deposited as Clavinema sp., may represent a wrong generic allocation, since Clavinema and Philometra have similar morphological traits resulting in taxonomic confusions. An example is that of Clavinema fujimotoi, originally described as Philometra fujimotoi (see [21]) and wrongly listed in the GenBank database (see sequence DQ076680 and Table 1). Moreover, species of Clavinema have a large anterior oesophageal bulb as one of the main generic diagnostic features, which may be confused with a similar structure present in some species of Philometra (e.g., P. coreii). Since there is no morphological reference specimen or scientific publication related to the sequence LC07153, we recommend considering Clavinema a monophyletic taxon.

The paraphyly of Dentiphilometra was confirmed [2,3], and D. monopteri a parasite of synbranchiform fish from Asia, seem to occupy a basal position within Philometridae, far from its congener Dentiphilometra sp. (possibly D. lutjani), a parasite of a perciform species from North America. This phylogenetic configuration apparently follows the general phylogenetic trends of their respective hosts, in which the order Synbranchiformes is basal compared to Perciformes [22].

It is still not fully clear how locality, host taxa and habitat are associated with the phylogenetic aspects of philometrid nematodes. However, well-supported clades were composed of taxa sharing similar geographic origin and habitat, e.g., that composed by A. amazonicum, $N$. senticosum, $R$. rumai and $P$. acreanensis (all parasitic in freshwater fishes from Amazonia). Furthermore, except for $P$. saltatrix, a parasite of Pomatomus saltatrix (Perciformes) from North American Atlantic coast, the assemblage where this species appeared was almost strictly composed by parasites of marine perciforms from Asia (with exception of $P$. thaiensis). Thus, it should be mentioned that the fish $P$. saltatrix has a wide geographic range, covering almost all subtropical marine waters (except eastern Pacific) [7]. This biological trait may explain the phylogentic proximity between $P$. saltatrix and the other species of Philometra in the same assemblage. The close relatedness of $P$. thaiensis, a parasite of Tetraodon biocellatus (Tetraodontiformes) from Asia, with species parasitic in marine perciform cannot be explained based on the present results, even though most of the referred taxa are originally from the same continent.

In the same sense, most species of Philometra and Philometroides, parasitic in Cypriniformes from continental waters of Eurasia, formed a clade with moderate nodal support, suggesting that the geographic origin, the host taxa and the habitat characteristics may be related to the evolutionary relationships of such parasites.

Even though some interesting aspects of the phylogeny and taxonomy of philometrids came to light, it is still early to draw definitive conclusions, because most of the genetic database is represented by one genetic marker (18S). Further integrative approaches using new genetic markers and morphological data should give more support to the issues observed in the present study. Anywise, it is suggestible that the host specificity of philometrids [1] plays an important role on their speciation process, as well as the geological history of the continents and of the Actinopterygii seem to retain phylogenetic information that may be related to some taxa of parasites, especially those infecting freshwater fishes.

\section{Acknowledgements}

Authors would like to thank Dr. Tomáš Scholz from the Laboratory of Helminthology, Institute of Parasitolgy of the Czech Academy of Sciences (IPCAS), on providing facilities for DNA isolation, PCR and sequencing of Philometra nattereri. Thanks are also due to Dr. Elias Nogueira de Aguiar from the Laboratório Multiusuário de Análises de Materiais do Instituto de Física (MULTILAM-INFI) da Universidade Federal de Mato Grosso do Sul (UFMS), for the help in scanning electron microscopical procedures.

\section{Funding}

This work was financed in part by the Coordenação de Aperfeiçoamento de Pessoal de Nível Superior-Brasil (CAPES)-Finance code 001 . M. T.-D. was supported by a researcher fellowship of the National Council for Research and Technological Development (Conselho Nacional de Pesquisa e Desenvolvimento Tecnologico, CNPq, Brazil)(\# 303013/2015-0). F. B. P. was supported by a Post-doctoral fellowship PNPD-CAPES (Programa Nacional de Pós-DoutoradoCoordenação de Aperfeiçoamento de Pessoal de Nível Superior-CAPES, Brazil).

\section{Appendix A. Supplementary data}

Supplementary data to this article can be found online at https:// doi.org/10.1016/j.parint.2018.10.010.

\section{References}

[1] F. Moravec, I. de Buron, A synthesis of our current knowledge of philometrid nematodes, a group of increasingly important fish parasites, Folia Parasitol. (Praha). 60 (2013) 81-101, https://doi.org/10.14411/fp.2013.010.

[2] M. Wijová, F. Moravec, A. Horák, J. Lukeš, Evolutionary relationships of Spirurina (Nematoda: Chromadorea: Rhabditida) with special emphasis on dracunculoid nematodes inferred from SSU rRNA gene sequences, Int. J. Parasitol. 36 (2006) 1067-1075, https://doi.org/10.1016/j.ijpara.2006.04.005.

[3] E. Černotíková, A. Horák, F. Moravec, Phylogenetic relationships of some spirurine nematodes (Nematoda: Chromadorea: Rhabditida: Spirurina) parasitic in fishes inferred from SSU rRNA gene sequences, Folia Parasitol. 58 (2011) 135-148, https://doi.org/10.14411/fp.2011.013.

[4] K.M.A. Quiazon, T. Yoshinaga, K. Ogawa, Philometra sawara sp. n. and a redescription of Philometra sciaenae Yamaguti, 1941 and Philometra nemipteri Luo, 2001 (Nematoda: Philometridae): a morphological and molecular approach, Folia Parasitol. (Praha). 55 (2008) 277-290, https://doi.org/10.14411/fp.2008.036.

[5] I. de Buron, S.G. France, V.A. Connors, W.A. Roumillat, L.C. Tsoi, Philometrids of the southern flounder Paralichthys lethostigma: a multidimensional approach to determine their diversity, J. Parasitol. 97 (2011) 466-475, https://doi.org/10. 1645/GE-2564.1.

[6] P.H.O. Cavalcante, F. Moravec, C.P. Santos, The philometrid nematode Philometroides acreanensis $\mathrm{n}$. sp. from the stomach wall of the catfish Pimelodus blochii in North-Western Brazil, J. Helminthol. 92 (2017) 109-115, https://doi.org/ 
10.1017/S0022149X1700013X

[7] D. Froese, R. Pauly, FishBase, http://www.fishbase.org, (2018) (accessed July 6, 2018).

[8] F. Moravec, Dracunculoid and Anguillicoloid nematodes parasitic in vertebrates, Academia, Prague, 2006

[9] G.B. Nunn, Nematode molecular evaluation, University of Nottinghan, UK, 1992.

[10] S. D'Amelio, K.D. Mathiopoulos, C.P. Santos, O.N. Pugachev, S.C. Webb, Genetic markers in ribosomal DNA for the identifcation of members of the genus Anisakis (Nematoda: Ascaridoidea) defined by polymerase chain reaction-based restriction fragment length polymorphism, Int. J. Parasitol. 30 (2000) 223-226.

[11] R.M. Floyd, A.D. Rogers, P.J.D. Lambshead, C.R. Smith, Nematode-specific PCR primers for the 18S small subunit rRNA gene, Mol. Ecol. Notes 5 (2005) 611-612, https://doi.org/10.1111/j.1471-8286.2005.01009.x.

[12] K. Katoh, K. Misawa, K. Kuma, T. Miyata, MAFFT: a novel method for rapid multiple sequence alignment based on fast Fourier transform, Nucleic Acids Res. 30 (2002) 3059-3066.

[13] C. Notredame, D.G. Higgins, J. Heringa, T-Coffee: a novel method for fast and accurate multiple sequence alignment, J. Mol. Biol. 302 (2000) 205-217, https://doi. org/10.1006/jmbi.2000.4042.

[14] J.M. Chang, P. Di Tommaso, C. Notredame, TCS: a new multiple sequence alignment reliability measure to estimate alignment accuracy and improve phylogenetic tree reconstruction, Mol. Biol. Evol. 31 (2014) 1625-1637, https://doi.org/10. 1093/molbev/msu117.

[15] S. Guindon, O. Gascuel, A simple, fast, and accurate algorithm to estimate large phylogenies by maximum likelihood, Syst. Biol. 52 (2003) 696-704, https://doi. org/10.1080/10635150390235520.

[16] J.P. Huelsenbeck, F. Ronquist, MRBAYES: Bayesian inference of phylogenetic trees,
Bioinforma. Appl. 17 (2001) 754-755, https://doi.org/10.1093/bioinformatics/17. 8.754.

[17] D. Darriba, G.L. Taboada, R. Doallo, D. Posada, jModelTest 2: more models, new heuristics and parallel computing, Nat. Methods 9 (2012) 772, https://doi.org/10 1038/nmeth.2109.

[18] S.-X. Wang, L. Li, L.-P. Zhang, Redescription and genetic characterization of Philometra lagocephali Moravec et Justine 2008 (Nematoda: Philometridae) from Lagocephalus lunaris (Bloch and Schneider) (Tetraodontiformes: Tetradontidae) in the South China sea, 60 (2015), pp. 395-406, https://doi.org/10.1515/ap-20150055 .

[19] K.M.A. Quiazon, T. Yoshinaga, H. Doi, J. Araki, K. Ogawa, First description of male Philometra thaiensis Moravec, Fiala et Dyková, 2004 (Nematoda: Philometridae) from the body cavity of the eyespot pufferfish Tetraodon biocellatus Tirant, and evolutionary relationships of this species with other dracunculo, Helminthologia 51 (2014) 236-245 (doi:10.2478/s11687-014-0235-6).

[20] F. Moravec, I. de Buron, Two new species of philometrid nematodes (Nematoda: Philometridae) from the southern flounder Paralichthys lethostigma in the estuaries of South Carolina, USA, Folia Parasitol. 53 (2006) 139-146.

[21] M. Margolis, F. Moravec, A record of Clavinema mariae (Layman, 1930) (Nematoda: Philometridae) from a north american freshwater fish, with notes on the systematic status of Philometra americana Kuitunen-Ekbaum, 1933, Folia Parasitol. 34 (1987) $31-36$.

[22] L.C. Hughes, G. Ortí, Y. Huang, Y. Sun, C.C. Baldwin, A.W. Thompson, Comprehensive phylogeny of ray-finned fishes (Actinopterygii) based on transcriptomic and genomic data, PNAS. (n.d.) 2-7. doi:https://doi.org/10.1073/pnas. 1719358115 